\title{
Teacher Upgrading Skill in Preparing Materials and Examination Based on Images in Sibolga City
}

\author{
Andriayani $^{1 *}$, Cut Fatimah Zuhra ${ }^{1}$, Awan Maghfirah ${ }^{2}$, Maulida Yanti ${ }^{3}$, Saharman Gea ${ }^{1}$, \\ Khatarina Meldawati Pasaribu ${ }^{1}$, Averrous Fazlurrahman Piliang ${ }^{2}$
}

\author{
${ }^{1}$ Department of Chemistry, Faculty of Mathematics and Natural Sciences, Universitas \\ Sumatera Utara, Jl. Bioteknologi No. 1, Medan, 20155, Indonesia \\ ${ }^{2}$ Department of Physics, Faculty of Mathematics and Natural Sciences, Universitas Sumatera \\ Utara, Jl. Bioteknologi No. 1, Medan, 20155, Indonesia \\ ${ }^{3}$ Department of Mathematics, Faculty of Mathematics and Natural Sciences, Universitas \\ Sumatera Utara, Jl. Bioteknologi No. 1, Medan, 20155, Indonesia \\ *Email : andriayani@usu.ac.id
}

\begin{abstract}
There are 61 primary/ibtidaiyah schools, 18 junior high schools, and 18 senior high schools in the city of Sibolga, which is located in Teluk Tapian Nauli, with a total number of teachers of about 2000. This is in line with the vision of Sibolga city (2016-2021) in order to create a stable, advanced, and successful Sibolga City by producing highly competitive quality human beings in order to create a harmonious, peaceful, secure and unified society. As mentioned above, one of its mission points is to prepare human resources (HR) that have integrity, reliable, competitive, expert in science and technology so that they able to compete in the global job market. As the education stakeholder, Sibolga Education and Culture Official has plan many outstanding work programs such as made a collaboration in partnership with the Universitas Sumatera Utara community service team. As a result, based on field observations and discussions, it was known that one of the obstacle that facing by the teachers in Sibolga is not being able to provide teaching materials and also picture-based examination questions as contained in the question grid. Currently, there are several technology-driven applications that can be used to make images or graphics creating process easier. Two of them are, GeoGebra Classic that used to create graphics and images in mathematics and Chemdraw that used to create structure images that related to chemistry. In addition word optimization training was also conducted to optimize teacher on preparing teaching materials with Ms. word.
\end{abstract}

\section{Keyword: Imaging Media, Teaching Materials, GeoGebra Classic, Chemdraw, Microsoft Word}

\begin{abstract}
Abstrak
Kota Sibolga yang terletak di Teluk Tapian Nauli memiliki 61 sekolah dasar/ibtidaiyah, 18 SLTP, dan SLTA 18 dengan total jumlah guru sekitar 2000 orang. Hal ini sejalan dengan visi Kota Sibolga (2016-2021) yaitu 'Mewujudkan Sibolga yang sejahtera, maju, dan berdaya saing', yaitu melalui pembangunan manusia yang berkualitas yang memiliki daya saing tinggi sehingga mampu membangun masyarakat yang rukun, damai, aman, dan bersatu. Dalam upaya mengembangkan visi di atas, salah satu butir misinya adalah bahwa pemerintah Kota Sibolga mempersiapkan sumberdaya manusia (SDM) yang memiliki integritas tinggi, handal, berdaya saing, menguasai ilmu pengetahuan dan teknologi sehingga mampu bersaing dalam pasar kerja global. Dinas Pendidikan dan Kebudayaan Kota Sibolga sebagai ujung tombak memajukan pendidikan telah bekerja keras menyiapkan beberapa program kerja unggulan, termasuk bekerjasa sama dengan tim pengabdian masyarakat dari Universitas Sumatera Utara (abdimas USU) untuk Tahun Akademik 2020. Sebagai hasil observasi di lapangan dan atas dasar diskusi yang dibangun dua arah yaitu antara mitra-tim abdimas USU diperoleh informasi bahwa salah satu kesulitan para guru di Kota Sibolga adalah tidak mampu menyediakan bahan ajar dan juga soal-soal ujian berbasis gambar sebagaimana telah dimuat dalam kisi-kisi soal. Pada masa sekarang ini, terdapat banyak aplikasi-aplikasi berbasis teknologi yang dapat dimanfaatkan untuk mempermudah dalam membuat gambar atau grafik yang diperlukan untuk membuat bahan ajar dan soal ujian berbasis gambar. Dua diantaranya adalah GeoGebra Classic
\end{abstract}


untuk mata pelajaran Matematika dan Chemdraw untuk mata pelajaran Kimia. Sebagai langkah untuk membantu mencari solusi dari permasalahan yang di hadapi dinas pendidikan dan kebudayaan Kota Sibolga, tim pengabdian kepada masyarakat USU memberikan pelatihan terkait penggunaan GeoGebra Classic untuk membuat grafik dan gambar di mata pelajaran matematika, pengunaan Chemdraw untuk membuat gambar terkait bidang kimia dan pengoptimasi penggunaan word untuk menyusun bahan ajar.

\section{Kata Kunci: Media Bergambar, Bahan Ajar, GeoGebra Classic, Chemdraw, Microsoft Word}

\section{PENDAHULUAN}

Kota Sibolga yang terletak di Teluk Tapian Nauli memiliki 61 sekolah dasar/ibtidaiyah, 18 SLTP, dan SLTA 18 dengan total jumlah guru sekitar 2000 orang. Hal ini sejalan dengan visi Kota Sibolga (2016-2021) yaitu 'Mewujudkan Sibolga yang sejahtera, maju, dan berdaya saing', yaitu melalui pembangunan manusia yang berkualitas yang memiliki daya saing tinggi sehingga mampu membangun masyarakat yang rukun, damai, aman, dan bersatu. Dalam upaya mengembangkan visi di atas, salah satu butir misinya adalah bahwa pemerintah Kota Sibolga mempersiapkan sumberdaya manusia (SDM) yang memiliki integritas tinggi, handal, berdaya saing, menguasai ilmu pengetahuan dan teknologi sehingga mampu bersaing dalam pasar kerja global.

Untuk mencapai visi di atas, kualitas pendidikan mendapat perhatian yang luar biasa. Dinas Pendidikan dan Kebudayaan Kota Sibolga sebagai ujung tombak memajukan pendidikan telah bekerja keras menyiapkan beberapa program kerja unggulan, termasuk bekerjasa sama dengan tim pengabdian masyarakat dari Universitas Sumatera Utara (abdimas USU) untuk Tahun Akademik 2020. Sebagai hasil observasi di lapangan dan atas dasar diskusi yang dibangun dua arah yaitu antara mitra-tim abdimas USU diperoleh informasi bahwa salah satu kesulitan para guru di Kota Sibolga adalah tidak mampu menyediakan bahan ajar dan juga soal-soal ujian berbasis gambar sebagaimana telah dimuat dalam kisi-kisi soal. Merujuk pada Peraturan Mendikbud No. 4 Tahun 2018 perihal tentang Penilaian Hasil Belajar oleh Satuan Pendidikan dan Penilaian Hasil Belajar oleh Pemerintah mendorong pencapaian standar kompetensi kelulusan secara nasional yaitu penyelenggaraaan ujian sekolah (US) dan atau/atau ujian sekolah berstandar nasional (USBN), dan ujian nasional (UN). Walaupun UN untuk Tahun Akademik 2020 ditiadakan karena mewabahnya virus corona-19 di seantero dunia. Khusus US, kententuan teknis pelaksanaannya didasarkan pada Permendikbud No. 53 Tahun 2015 tentang Penilaian Hasil Belajar oleh Pendidik dan Satuan Pendidikan pada Pendidikan Dasar dan Pendidikan Menengah. Merujuk pada kedua keputusan di atas maka dapat disimpulkan bahwa peran pendidik dan satuan pendidikan semakin diberi ruang dan kesempatan untuk terlibat secara aktif dalam meningkatkan kualitas penyelenggaraan pendidikan, menentukan kompetensi lulusan, dan juga mengukur kesuksesan lembaga pendidikannya sendiri.

Bahan ajar adalah segala sesuatu yang dipersiapkan oleh setiap pendidik untuk menyajikan atau menyampaikan bahan ajarnya yang dikenal dengan kurikulum tingkat satuan pendidikan (KTSP). Hal ini merujuk pada Permendikbud N0. 41 Tahun 2007 tentang Standar Proses dimana perencanaan proses pembelajaran meliputi pengembangan silabus dan rencana perlakuan pembelajaran (RPP) harus dikembangkan sendiri oleh pendidik.

Agar bahan ajar dapat ditransfer secara efektif kepada peserta didik, media gambar adalah salah satu pilihan yang tepat. Gambar disediakan sedemikian rupa dalam dua dimensi sehingga memudahkan penyempaian informasi dibandingkan dengan penyedian lewat penjelasan saja dalam bentuk kata- 
kata (Suleiman, 2008). Dengan media gambar akan terjadi peningkatan interaksi pemateri-peserta didik karena mampu memanipulasi dan bahkan mengendalikan perintah atau prilaku penerima informasi (reseptor) untuk memahami materi pembelajaran (Prastowo, 2014).

Hal yang sama dapat diaplikasikan pada penyiapan soal berbasis gambar sebagai langkah evaluasi hasil belajar baik dari aspek kognitif, afektif, maupun psikomotorik. Hasil evaluasi belajar dapat digunakan sebagai alat ukur kualitas proses belajar-mengajar dalam periode tertenu yang telah disepakati. Kualitas soal ujian harus mendapat perencanaan yang baik mengikuti taksonomi Bloom dari aspek kogniitif meliputi pengetahuan (C1), Pemahaman (C2), aplikasi (C3), analisis (C4), evaluasi (C5) dan kreatif (C6). Butir soal dengan tingkatan C4-C6 biasanya akan lebih mudah bila disajikan dalam bentuk media gambar. Soal pada tingkatan ini sering dikenal dengan higher order thingking skill (HOTS).

Seiring dengan kemajuan teknologi dan berkembang pesatnya software sederhana yang dapat dimanfaatkan untuk pembuatan gambar, maka pada kegiatan ini tim abdimas USU akan memberi pemahaman, penjelasan, pelatihan dan pendampingan bagi guru-guru sebanyak 40 orang dari berbagai sekolah yang ada di Kota Sibolga. Karena keterbatasan waktu dan juga agar diperoleh hasil yang lebih optimal maka kegiatan ini hanya dibatasi dan difokuskan pada pemberian transformasi ilmu pemanfaatan software GeoGebra Classic 6 untuk mata pelajaran Matematika dan Chemdraw untuk mata pelajaran Kimia. Diharapkan setiap peserta agar berpartisipasi membawa laptop masingmasing yang akan diinstal dengan software di atas oleh tim abdimas USU. Perihal kurikulum, RPP, KSTP, dan kisi-kisi soal dianggap telah diketahui dengan benar oleh mitra.

\section{METODE PELAKSANAAN}

Setelah diskusi dengan mitra dan melihat software yang akan dijelaskan untuk digunakan oleh mitra, tim abdimas USU memilih beberapa metode yang dianggap efektif dalam transfer ilmu yaitu diskusi, pelatihan penggunaan beberapa software terkait, konsultasi, pendampingan dan evaluasi.

Adapun tahapan pelaksanaan kegiatan disesuaikan dengan masalah mitra sebagai berikut:

1. Memberikan motivasi bahwa guru harus mampu membangun kapasitas (membuka cakrawala pemikiran) dan kapabilitas (kemampuan) diri dalam mengiktui setiap perkembangan teknologi yang berhubungan dengan pengembangan diri (building capacity).

2. Menanamkan rasa percaya diri bahwa seetiap guru pasti bisa menyiapkan bahan ajar membuat soal-soal ujian, khusus kaitannya dengan media bergambar.

3. Memperkenalkan dan memberi pendampingan penggunaan software GeoGebra Classic, dan Chemdraw.

4. Mengajarkan bagaimana mengimport dan menyimpan data ke dalam kertas kerja menggunakan microsoft word.

5. Memberikan kesempatan untuk diskusi dalam jarak jauh dengan para peserta.

6. Mengevaluasi hasil kreasi gambar yang telah dibuat oleh mitra dan memberikan umpan balik (feed back). 


\section{Prosedur Kegiatan dan Partisipasi Mitra dalam Pelaksanaan Program}

Kegiatan ini akan berhasil sesuai dengan indikator capaian yang ditargetkan dan bermanfaat bila kegiatan direncanakan dengan baik disertai oleh partisipasi aktif dari mitra. Tabel 2.1. di bawah ini menyampaikan rencana kegiatan dan partisipasi dari mitra.

\begin{tabular}{|c|c|c|c|c|}
\hline No & Aplikasi Kegiatan & $\begin{array}{c}\text { Metode } \\
\text { Pendekatan }\end{array}$ & Target & Partisipasi Mitra \\
\hline 1. & $\begin{array}{l}\text { Motivasi dan } \\
\text { menanamkan rasa } \\
\text { percaya diri }\end{array}$ & $\begin{array}{l}\text { Penjelasan dan } \\
\text { diskusi }\end{array}$ & $\begin{array}{l}\text { Mitra (para } \\
\text { guru) }\end{array}$ & $\begin{array}{l}\text { Menyampaikan kesulitan } \\
\text { yang mereka hadapi perihal } \\
\text { pembuatan media gambar }\end{array}$ \\
\hline 2. & Menginstal software & $\begin{array}{l}\text { Penjelasan dan } \\
\text { diskusi }\end{array}$ & $\begin{array}{l}\text { Mitra (para } \\
\text { guru) }\end{array}$ & $\begin{array}{l}\text { Menyediakan tempat, } \\
\text { proyektor, hadir pada } \\
\text { kegiatan, aktif dalam } \\
\text { diskusi dan tanya jawab } \\
\text { untuk hal-hal yang belum } \\
\text { dipahami }\end{array}$ \\
\hline 3. & $\begin{array}{l}\text { Operasional } \\
\text { penggunaan } \\
\text { GeoGebra }\end{array}$ & $\begin{array}{l}\text { Pelatihan dan } \\
\text { pendampingan } \\
\text { penggunaan } \\
\text { software } \\
\text { GeoGebra }\end{array}$ & $\begin{array}{l}\text { Mitra (para } \\
\text { guru } \\
\text { Matematika } \\
\text { atau campuran) }\end{array}$ & $\begin{array}{l}\text { Menyediakan tempat, } \\
\text { setiap peserta membawa } \\
\text { laptop, dan berlatih } \\
\text { membuat gambar pada } \\
\text { mata pelajaran matematika. }\end{array}$ \\
\hline 4. & $\begin{array}{l}\text { Operasional } \\
\text { penggunaan } \\
\text { Chemdraw }\end{array}$ & $\begin{array}{l}\text { Pelatihan dan } \\
\text { pendampingan } \\
\text { penggunaan } \\
\text { software } \\
\text { Chemdraw }\end{array}$ & $\begin{array}{l}\text { Mitra (para } \\
\text { guru Kimia } \\
\text { atau campuran) }\end{array}$ & $\begin{array}{l}\text { Menyediakan tempat, setiap } \\
\text { peserta membawa laptop, } \\
\text { dan berlatih membuat } \\
\text { gambar pada mata pelajaran } \\
\text { Kimia. }\end{array}$ \\
\hline 5. & $\begin{array}{l}\text { Optimasi } \\
\text { Penggunaan Word }\end{array}$ & $\begin{array}{l}\text { Pelatihan dan } \\
\text { pendampingan } \\
\text { penggunaan } \\
\text { Microsoft word }\end{array}$ & $\begin{array}{l}\text { Mitra (para } \\
\text { guru Fisika } \\
\text { atau campuran) }\end{array}$ & $\begin{array}{l}\text { Menyediakan tempat, setiap } \\
\text { peserta membawa laptop, } \\
\text { dan berlatih } \\
\text { memoptimasikan } \\
\text { penggunaan word. }\end{array}$ \\
\hline 6. & $\begin{array}{l}\text { Latihan pembuatan } \\
\text { gambar dan } \\
\text { menyisipkan dalam } \\
\text { dokumen }\end{array}$ & $\begin{array}{l}\text { Pendampingan dari } \\
\text { tim abdimas USU }\end{array}$ & $\begin{array}{l}\text { Mitra (para } \\
\text { guru) }\end{array}$ & $\begin{array}{l}\text { Menyelesaikan bahan } \\
\text { latihan. }\end{array}$ \\
\hline 7. & Latihan lanjutan & $\begin{array}{l}\text { Pendapingan jarak } \\
\text { jauh secara daring }\end{array}$ & $\begin{array}{l}\text { Mitra (para } \\
\text { guru) }\end{array}$ & $\begin{array}{l}\text { Secara aktif menghubungi } \\
\text { tim pendamping. }\end{array}$ \\
\hline 8. & Evaluasi & $\begin{array}{l}\text { Evaluasi dan } \\
\text { penetuan hasil }\end{array}$ & $\begin{array}{l}\text { Mitra (para } \\
\text { guru) }\end{array}$ & $\begin{array}{l}\text { Secara aktif menghubungi } \\
\text { tim pendamping. }\end{array}$ \\
\hline
\end{tabular}

Tabel 2.1. Rencana Kegiatan dan Partisipasi Mitra

\section{HASIL DAN PEMBAHASAN}

Untuk melaksanakan kegiatan pengabdian tim pengabdian telah mempersiapkan materi yang disampaikan kepada mitra pengabdian. Berikut adalah beberapa kegiatan yang sudah dilakukan dalam pengabdian kepada masyarakat yang dilakukan di kota Sibolga. 
1. Pembuatan video panduan dasar menginstall dan menggunakan GeoGebra Classic untuk membuat gambar dan grafik.

2. Persiapan sebelum pelatihan

3. Pelaksanaan pelatihan.

Ada tiga video berdurasi 7 sd 10 menit terkait panduan dasar GeoGebra Classic yang sudah dibuat. Video pertama memuat penjelasan tentang cara menginstall GeoGebra Classic. Video kedua memuat penjelasan singkat terkait jendela, menu dan tools yang ada di Geogebra. Video terakhir berisi beberapa contoh cara membuat grafik dan gambar menggunakan GeoGebra. Begitu juga dengan slide Geogebra dan Chemdraw dapat dilihat layoutnya pada Gambar 3.1 dibawah ini
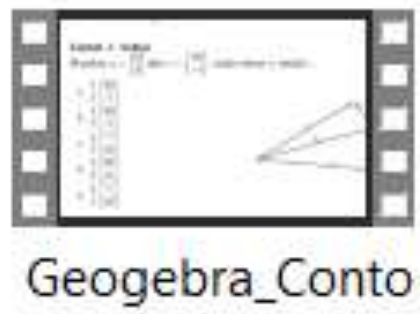
h1

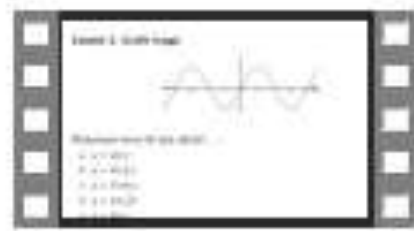

geogebra_conto

h2
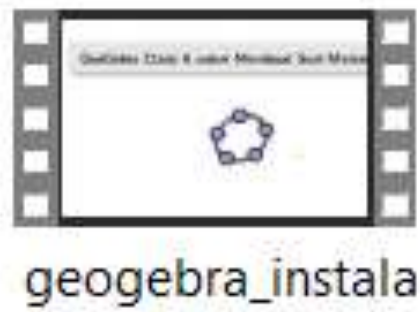
sidanMenudasar
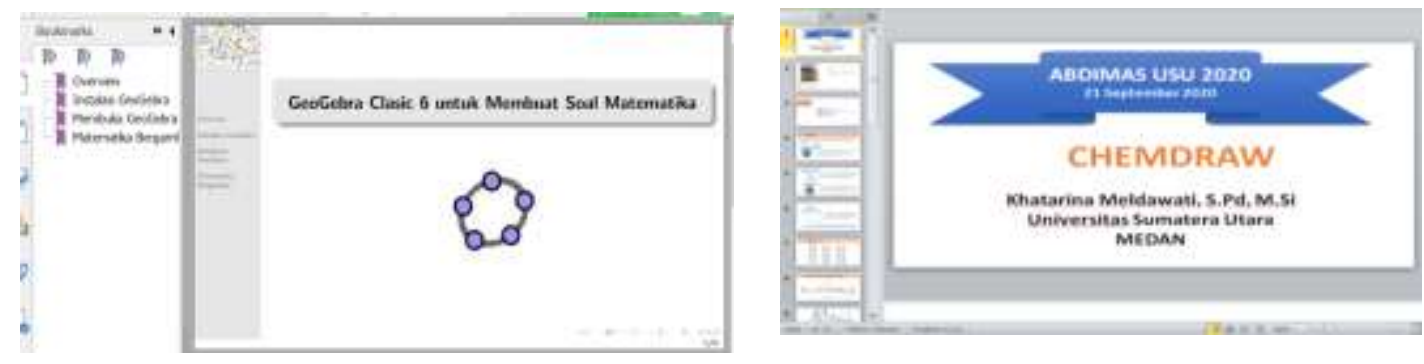

Gambar 3.1. Layout video dan slide pelatihan GeoGebra dan Chemdraw

Kegiatan pengabdian ini dilakukan oleh tim pengabdian kepada masyarakat pada hari Senin, tanggal 21 September 2020. Tim berangkat dari medan menggunakan jalur darat di hari sabtu sebelumnya. Kegiatan dilakukan di Aula SMP 1 Sibolga. Kegiatan dilakukan pada dua ruangan dengan jumlah peserta masing-masing 10 orang. Kegiatan ini dilakukan pada masa pandemi Covid-19 sehingga kegiatan dilakukan dengan mematuhi protokol kesehatan. Tim menyediakan tempat cuci tangan dan masker dapat dilihat pada Gambar 3.2 di bawah ini. 

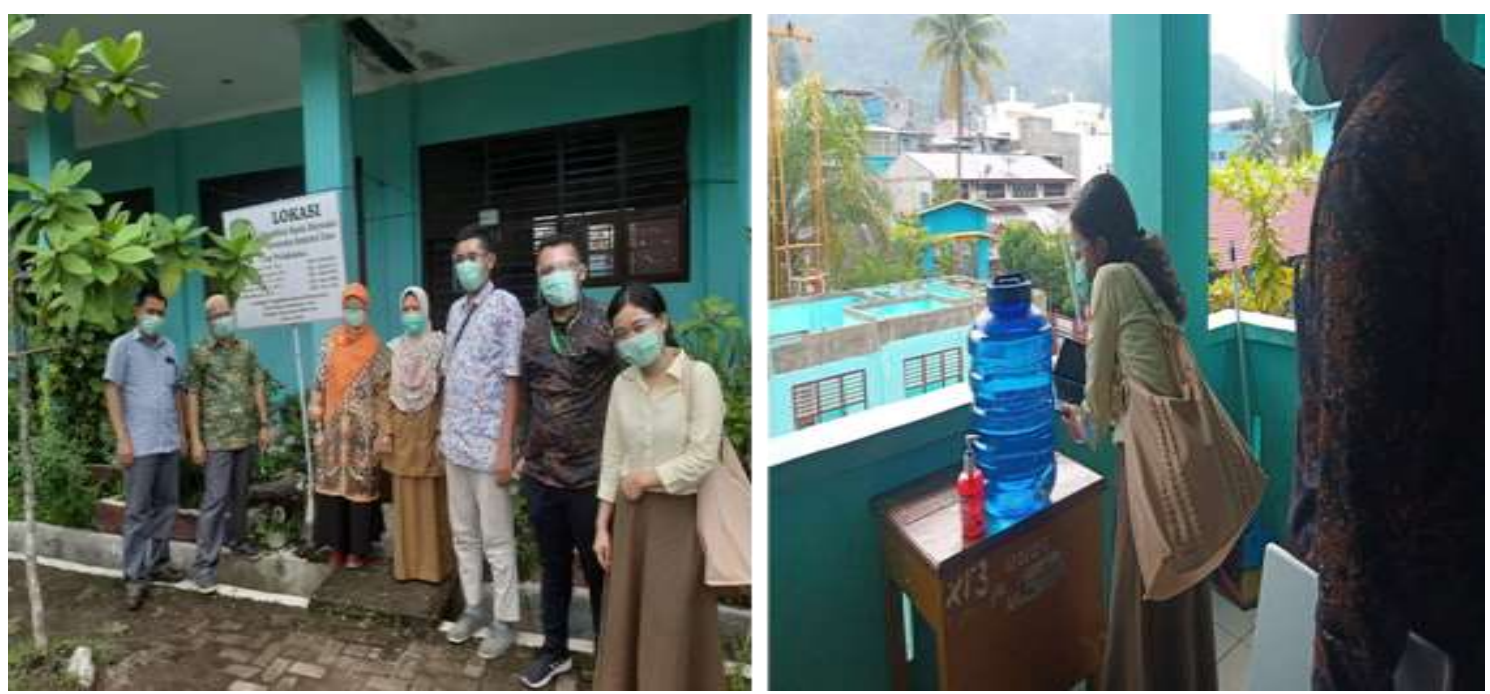

Gambar 3.2. Lokasi Pengabdian di SMP 1 Sibolga (kiri) dan tempat cuci tangan (kanan)

Pelatihan dan sosialisasi dilakukan senin, 21 september 2020 di aula SMP 1 Sibolga. Pelatihan di mulai dengan kata pembukaan dari tim pengabdian USU lalu yang kemudian diikuti kata sambutan oleh Kepala Dinas Pendidikan dan Kebudayaan Kota Sibolga dapat dilihat pada Gambar 3.3 dibawah ini.
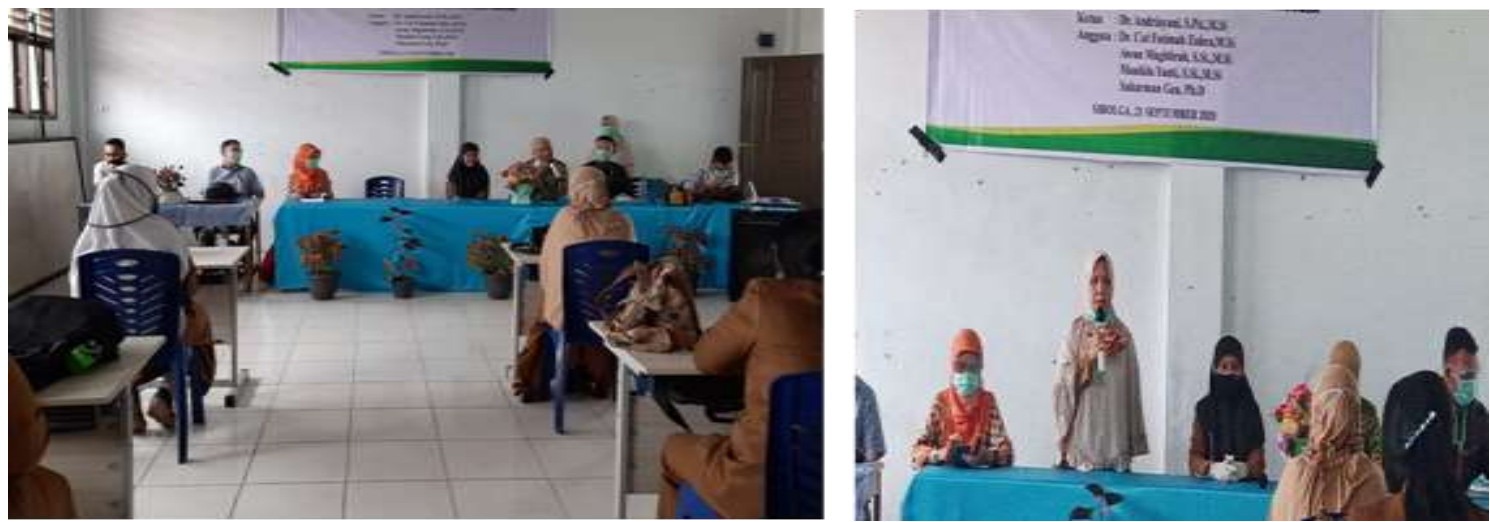

Gambar 3.3. Penyampaian kata pembukaan oleh tim pengabdian USU dan kata sambutan oleh Kepala Dinas Pendidikan dan Kebudayaan Kota Sibolga

Setelah pembukaan dilakukan peserta diarahkan ke kelas masing-masing untuk mengikuti pelatihan. Ada tiga jenis pelatihan yang diberikan yaitu pelatihan terkait GeoGebra untuk membuat soal matematika bergambar, pelatihan dasar cara menggunakan Chemdraw dan pelatihan pengoptimasi penggunaan word. Pelatihan yang telah dilaksanakan dapat dilihat pada Gambar 3.4 dibawah ini. 

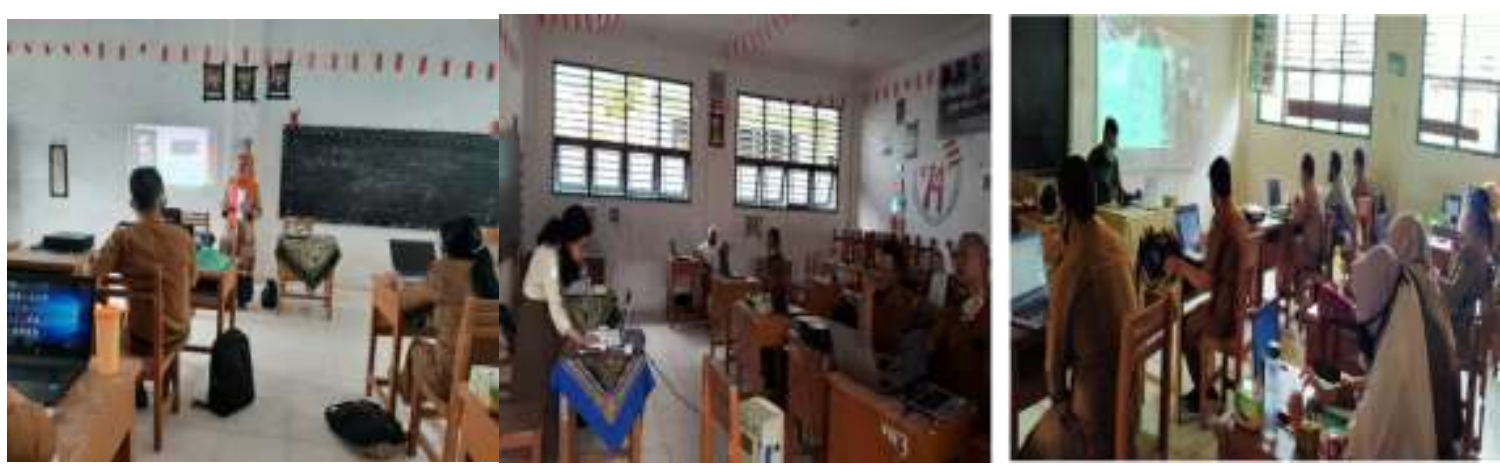

Gambar 3.4. Proses pelaksanaan pelatihan

\section{KESIMPULAN}

Adapun kesimpulan yang diperoleh dari kegiatan pengabdian masyarakat di Kota Sibolga yaitu,

1. Kegiatan pengabdian masyarakat yang telah dilakukan mendapatkan respon yang sangat baik dari Kepala Dinas Pendidikan dan Kebudayaan Kota Sibolga dan Guru-guru di Sibolga.

2. Terjadi peningkatan kemampuan guru khususnya kemampuan akan penggunaan software dalam membuat gambar sebagai objek dari pengabdian masyarakat ini.

3. Guru memiliki kemampuan menggunakan software untuk membuat gambar dan grafik yang dapat digunakan dalam pembuatan bahan ajar dan soal ujian berbasis gambar.

\section{UCAPAN TERIMAKASIH}

Terimakasih kepada Rektor USU yang telah mendukung dan memfasilitasi tim pengabdian skema Dosen Mengabdi melalui dana NON PNBP USU dengan Nomor: 288/UN5.2.3.2.1/PPM/2020, dan juga kepada mitra pada kegiatan ini.

\section{DAFTAR PUSTAKA}

Prastowo, A. 2014. Panduan Kreatif Membuat Bahan Ajar Inovatif. Jogjakarta: Diva Press. Suleiman, Hamzah. 2008. Media Audio-Visual. Jakarta: PT Gramedia.

Triwahyuningtyas, D., Rahayu, S., \& Agustin, W. D. (2019, November). The impact of geogebra classic application on learning geometry. In Journal of Physics: Conference Series (Vol. 1381, No. 1, p. 012033). IOP Publishing.

S. Kocman, P. Orsag, and P. Pecinka, "Simulation of selected induction motor operating conditions using COMSOL software," Adv. Electr. Electron. Eng., vol. 16, no. 3, pp. 288-296, 2018, doi: 10.15598/aeee.v16i3.2824.

Adhemar, Enrietti, and Mieres Franco, "ENSEÑANZA DE LA CATEDRA ELECTROTECNIA Y MAQUINAS ELÉCTRICA,”pp. 1-8, 2012.

D. Cézar and S. De Assunção, "Software Livre e Engenharia Elétrica." 